Revista lus et Praxis, Año 24, No 1, 2018, pp. 329 - 360

ISSN 0717 - 2877

Universidad de Talca - Facultad de Ciencias Jurídicas y Sociales

Las restituciones consecutivas a la nulidad o resolución en los contratos de bienes muebles

Rodrigo Momberg Uribe y Carlos Pizarro Wilson

Trabajo recibido el 9 de agosto de 2016 aprobado el 24 de octubre de 2016

\title{
Las restituciones consecutivas a la nulidad o resolución en los contratos de bienes muebles*
}

\author{
Mutual Restitution in CASES OF NUlLity AND termination \\ IN CONTRACTS RELATED TO MOVABLE PROPERTY
}

Rodrigo Momberg Uribe** y Carlos Pizarro Wilson***

\begin{abstract}
RESUMEN
El artículo analiza algunos problemas específicos en el ámbito de las restituciones consecutivas a la nulidad o resolución de contratos cuyo objeto son bienes muebles y servicios. El estudio incluye el análisis de la retroactividad como efecto de la nulidad y la resolución, la distinción de los efectos de las restituciones en contratos de ejecución instantánea y de ejecución continua o a tractos, el destino de los frutos y otros beneficios obtenidos en el tiempo intermedio, las relaciones entre el efecto restitutorio y la indemnización de perjuicios, los riesgos y los acuerdos que las partes pudiesen concluir respecto a la materia. Se concluye con una propuesta normativa para una futura reglamentación.
\end{abstract}

PALABRAs CLAVE

Restituciones - Nulidad - Resolución por incumplimiento.

ABSTRACT

The paper analyses some particular problems related with mutual restitution in cases of nullity or termination of contracts related to movable property. The study includes the analysis of retroactivity as effect of nullity and termination, the effects of restitution in discrete and long term contracts, the apportionment of fruits and benefits obtained before restitution, the relationship between restitution and damages, the allocation of risks and the agreements of the parties on the matter. It is concluded with a normative proposal for a future regulation.

KEYWORDS

Restitution - Nullity - Termination of contract.

\footnotetext{
* Este artículo forma parte del Proyecto Redes de Cooperación Internacional REDES 130097, financiado por el Conicyt.

** Profesor de Derecho Privado, Escuela de Derecho, Pontificia Universidad Católica de Valparaíso (Chile). Visiting Research Fellow, Instituto de Derecho Europeo y Comparado, Universidad de Oxford. PhD, Universidad de Utrecht. Correspondencia a: Avenida Brasil 2950, Valparaíso. Correo electrónico: rodrigo.momberg@pucv.cl

*** Profesor Investigador Facultad de Derecho de la Universidad Diego Portales, Santiago, Chile. Doctor en Derecho Universidad Paris II (Panthéon-Assas). Correspondencia a: República 112, Santiago. Correo electrónico carlos.pizarro@udp.cl.
} 


\section{Introducción}

Las restituciones consecutivas, aunque eventuales, en caso de nulidad o resolución, sólo han recibido un tratamiento marginal en nuestra doctrina. ${ }^{1}$ Su interés, sin embargo, es mayúsculo, si consideramos que una vez declarada la nulidad o la resolución de la venta, ya sea por vicios intrínsecos o problemas de incumplimiento, las partes pueden verse enfrentadas a restituir aquello que han recibido en virtud del contrato, con independencia de quien ha ocasionado el vicio o ha incumplido el contrato e, incluso, si concurre o no culpa contra quien se reclaman las restituciones. En las líneas que siguen, nos proponemos analizar algunos problemas específicos en el ámbito de las restituciones consecutivas a la nulidad o resolución de contratos cuyo objeto son bienes muebles. Se intenta responder cuál es el sistema más idóneo de restituciones en el evento que se verifique un concurso de acciones que puedan desencadenar la nulidad o la resolución de tales contratos. ${ }^{2}$ El problema planteado puede apreciarse claramente en el marco del concurso de acciones del comprador en caso de disconformidad de lo recibido con aquello contratado. En otros términos, el comprador tiene a su disposición una acción de nulidad, pero también podría detentar una de resolución al concurrir disconformidad entre la cosa que debía entregarse y aquella recibida, de acuerdo al artículo 1828 del Código Civil. Se trata de una entrega defectuosa, al existir disconformidad entre lo recibido y lo pagado, lo que puede decantar en cuanto a la calificación jurídica en un defecto susceptible de nulidad o un genuino cumplimiento imperfecto. ${ }^{3}$

Ya ha sido dicho que son diversas acciones las que puede intentar el comprador para alcanzar satisfacción, desde el ámbito de las ineficacias intrínsecas, como la nulidad en caso de error o dolo, hasta aquellas de índole extrínsecas, como la resolución o redhibitoria o aun ingresar en el ámbito propio de la responsabilidad contractual en forma conjuntiva o autónoma, según se prefiera, sobre todo si la acción, al menos en el derecho europeo, se funda en la responsabilidad por productos defectuosos, régimen, como se sabe, que en Chile aún se ignora en la legislación. ${ }^{4}$

\footnotetext{
1 En Chile puede consultarse, Bécar (2010), pp. 133 y ss.; alCalde y Vives (inédito); Pinochet y Concha (2015) aunque no en forma central, también lo analiza CONTARDO (2011), pp. 85-118. Puede también consultarse en general la obra de AlESSANDRI (2011).

2 Descartamos el análisis del problema en el ámbito del consumo y en el Código de Comercio.

3 De la Maza (2012).

4 Se trata de un problema tratado in extenso en Chile. Entre otros, BARRIENTOS (2010); CORRAL (2006).
} 
Desde hace algunos años, incluso en Chile, este tema del concurso ha recibido atención, tanto a nivel doctrinal como jurisprudencial, existiendo, pareciera ser, bastante tolerancia de la jurisprudencia a la hora de acoger la acción incoada por el comprador. Así lo muestra por ejemplo el fallo en el denominado caso "Salinak", ${ }^{5}$ que coloca el acento en el concurso entre el vicio del error sustancial y la falta de conformidad, de acuerdo al artículo 1828 relativa a la compraventa que posibilita la acción de resolución. El referido fallo sostuvo, luego de citar el artículo 1828 que obliga al vendedor a entregar lo que reza el contrato, que si bien "en el caso de autos el vendedor cumplió con su obligación de entregar la cosa, la sal, lo hizo en forma imperfecta al entregar sal en una concentración distinta a la requerida por el comprador. Esta materia se encuentra tratada en el artículo 1454 del Código Civil, referida al error de hecho que se produce cuando "la sustancia o calidad esencial del objeto sobre el que versa el acto o contrato, es diversa de lo que se cree" ${ }^{6}{ }^{6}$

La Corte Suprema asumió que existía tal concurso, pero al no haberse incoado la acción de nulidad por error, sólo se concentró en sede casación en la acción resolutoria, desestimando la acción redhibitoria y accediendo, por cierto, a la indemnización con carácter autónomo. ${ }^{7}$

Sin embargo, esta atención doctrinal y, por cierto, en alguna medida jurisprudencial, no se ha reflejado en el ámbito de los efectos que pueden generar esas mismas acciones si fueren acogidas por sentencia judicial o hubieren operado por vía extrajudicial, al menos en el caso de la resolución como efecto del pacto comisorio calificado o en presencia de una genuina cláusula resolutoria. El reconocimiento a la elección del acreedor o el comprador en caso de concurso deja el asunto de los efectos en la primera escena, siendo éstos, en una gran medida, los que debieran definir la elección.

Hay que tener presente que en derecho comparado no existe uniformidad en cuanto al concurso entre error e incumplimiento. Así, por ejemplo, los Principios de Derecho Europeo de Contratos (PECL) y el Borrador del Marco Común de Referencia (DCFR) otorgan al contratante que tiene derecho a demandar la nulidad, la alternativa de optar por alguna de las acciones derivadas del incumplimiento contractual, si concurren en el caso los requisitos para ello. ${ }^{8}$

\footnotetext{
5 De la Maza y Vidal (2014); Cecinas La Preferida S.A. con Sociedad Comercial Salinak Limitada (2006) Corte Suprema, 27 de julio de 2005, rol 5320-2003.

6 Cecinas La Preferida S.A. con Sociedad Comercial Salinak Limitada (2006) Corte Suprema, 27 de julio de 2005, rol 5320-2003.

7 Sobre este otro problema, ya superado en parte en la jurisprudencia, LóPEZ (2010).

8 Artículo 4:119: Acciones para casos de incumplimiento. La parte que tenga derecho a ejercitar alguna de las acciones de este capítulo en circunstancias que le den también derecho a aplicar acciones para
} 
En cambio los Principios Unidrot sobre Contratos Comerciales Internacionales (PICC) rechazan el concurso, en el sentido que imponen al contratante afectado la obligación de tener que optar por los remedios que le otorga el incumplimiento contractual por sobre la anulación del contrato por error. ${ }^{9}$ Esta última alternativa se justifica en los comentarios oficiales, ya que los remedios por incumplimiento contractual serían más adecuados y flexibles que los efectos que sobre el contrato produce la nulidad por error. ${ }^{10}$

Asumiendo que existe un concurso de acciones en el evento que la cosa entregada sea diversa a la contratada, pudiendo verificarse las condiciones de la acción de nulidad relativa y aquella resolutoria, resulta importante tener claridad acerca de los efectos restitutorios consecutivos a la declaratoria de nulidad o resolución. No se trata sólo de un ejercicio comparativo, sino analítico de lo que significa, conforme el concurso de acciones, preferir una u otra a propósito de sus efectos.

Se trata de un asunto poco explorado en el medio local, quizá por el hecho que involucra el análisis de las restituciones consecutivas a la declaración de nulidad o resolución del contrato que, honestidad obliga, suele ser uno de los asuntos más aburridos en el derecho de las obligaciones y el derecho de bienes. ${ }^{11}$ Tanto es así que los profesores de Derecho Civil suelen rehuir su estudio acabado imputando su análisis a distintos momentos de los programas, ya sea la acción reivindicatoria, los efectos de la resolución o incluso la nulidad.

Este mismo desdén hacia el estudio de las restituciones ha significado una asimilación, algo irreflexiva, del denominado efecto retroactivo de la nulidad previsto en el artículo 1687 a la resolución, la que, sin embargo, al menos en su tratamiento como "condición", ya sea "suspensiva" o "resolutoria", contempla reglas especiales, al igual que la resolución por incumplimiento del pago del precio en la compraventa, conforme el artículo 1875 del Código Civil.

casos de incumplimiento, puede utilizar cualquiera de dichos medios. La misma norma se contempla en el DCFR, art II.- 7:216. La misma opción aparece en los Principios Latinoamericanos de Derecho de los Contratos en su versión actual. El precepto en cuestión sostiene que "La parte que tenga derecho a demandar la nulidad del contrato y, al mismo tiempo, pueda ejercer alguno de los medios de tutela por incumplimiento, podrá optar entre aquella y estos".

9 Art. 3.2.4: "(Remedios por incumplimiento) Una parte no puede anular el contrato a causa de error si los hechos en los que basa su pretensión le otorgan o le podrían haber otorgado remedios por incumplimiento".

10 La explicación no ha sido desarrollada y, en general, se ha dicho que por lógica sería mejor la opción o que no habría buenas razones para impedirlo. Como se analizará en este trabajo, las razones pueden encontrarse en los efectos consecutivos a la nulidad o resolución o incluso respecto a determinados remedios particulares y, también, en la relación con la indemnización de daños, ya sea por el régimen aplicable o su incardinación con los daños específicos. Diez-Pıcazo et al. (2002), pp. 246 y 247.

11 Benabant (2008), p. 15. 
Para entender este asunto debemos indicar que nos referiremos sólo a las restituciones entre las partes, excluyendo el tratamiento de los efectos respecto de terceros. ${ }^{12}$ Tampoco aludiremos a los bienes inmuebles, cuyo tratamiento incide en la acción reivindicatoria o la acción restitutoria de acuerdo al sistema registral chileno, que distingue entre el título y el modo como mecanismo de transferir el dominio. ${ }^{13}$

Nuestro estudio, partiendo de la base de la compraventa de bienes muebles, pero que podría también extenderse a otros contratos que tengan por objeto bienes de dicha naturaleza, como asimismo a contratos de servicios, pretende analizar los efectos de la nulidad y resolución, lo que amerita examinar no sólo el pretendido efecto retroactivo que les sería común, sino que aclarar si dicho efecto que entendemos no reviste el carácter de retroactivo, constituye una acción o una genuina consecuencia ineluctable de la sentencia declaratoria de nulidad o resolución, lo que nos permitirá aplicarlo a contratos de ejecución instantánea, diferenciándolos de aquellos de ejecución sucesiva y terminando con la necesaria compatibilidad con los daños cuya indemnización sea procedente.

\section{La retroactividad ${ }^{14}$}

Un primer problema, quizá más bien teórico, incide en considerar si la retroactividad constituye el monopolio de la nulidad o, en cambio, debe considerarse también a propósito de la resolución, ya sea en forma total o, al menos, parcial. Dicha idea de retroactividad, con los límites basados en la buena fe y la apariencia, considera pertinente excluir el contrato como fenómeno jurídico, constituyendo una ficción que permita situar a las partes a la época anterior a la celebración del contrato, como si el contrato no hubiere existido.

Una reciente sentencia de la Corte Suprema así lo reconoce, citando a Claro Solar, al sostener que "una vez declarada, la condición resolutoria produce efectos retroactivos, volviendo a las partes al estado jurídico en el que se encontraban previo a contratar, como si no hubiesen convenido... revocando, borrando todas consecuencias del contrato, obra, ex tunc, el aniquilamiento

\footnotetext{
12 Es fácil advertir una diferencia relevante en este ámbito entre la nulidad y la resolución, mientras la primera hace procedente la acción reivindicatoria sin limitaciones conforme el artículo 1687 del Código Civil, aquella resolutoria queda circunscrita a las condiciones previstas en los artículos 1490 y 1491 del Código Civil. Sobre esto, Peñailillo (2003), p. 453.

13 Peñallillo (2011), pp. 196, 208 y ss.

14 Reproducimos acá parte del artículo publicado en Pizarro (2011), pp. 449 y ss. Más reciente y documentado, CONTARDO (2015).
} 
del contrato mismo"115. Esta idea de retroactividad, instalada en la resolución, pareciera originarse en la analogía con la nulidad del contrato, cuyo efecto, en ese caso, por la naturaleza de la sanción intrínseca, en forma correcta destruye el vínculo contractual. En este sentido, López Santa-María sostiene que "El efecto de la resolución, acogida por sentencia judicial firme, es la desaparición retroactiva del contrato. Lo mismo cuando se pronuncia judicialmente la nulidad de un contrato" y se agrega "es como si el contrato nunca hubiese existido", y se afirma, en definitiva, que se aplican las reglas de las prestaciones mutuas insertas a propósito de la acción reivindicatoria. ${ }^{16}$

Sin embargo, en un examen más detallado, tales afirmaciones dejan de ser evidentes. Así, si uno observa el tratamiento de la nulidad a propósito de las restituciones, debe considerar los artículos 1687 y 1689, que ratifican la necesidad de retrotraer a las partes al estado anterior a la celebración del contrato. Dicho efecto retroactivo en la nulidad por texto expreso involucra que las restituciones queden gobernadas por las reglas aplicables a las prestaciones mutuas reguladas a propósito de la acción reivindicatoria, distinguiendo en lo esencial, si el poseedor vencido estaba de buena o mala fe. En cambio, tratándose de la resolución, las restituciones se rigen por lo dispuesto en los artículos 1487 y siguientes, cuyo tratamiento difiere de aquel de la nulidad, al menos en algunos aspectos particulares y solo a título subsidiario se aplican las reglas de las prestaciones mutuas.

Pero aún más, lo concreto es que la desaparición del contrato en el caso de la resolución es siempre eventual, pues exige que se hayan ejecutado las obligaciones y sobre todo, tratándose de terceros admite límites expresos en los artículos 1490 y 1491 del Código Civil. En caso de resolución el contenido del contrato relativo al incumplimiento pervive y es esencial considerarlo a efectos de dirimir el litigio. Así ocurre con las cláusulas penales, limitativas, exonerativas o de otra índole que aludan al incumplimiento. En una reciente sentencia se destaca este efecto en los siguientes términos:

"Lo que ocurre una vez declarada la resolución de un contrato es que afloran sus efectos, los que son diversos según la naturaleza de las obligaciones y si éstas fueron o no ejecutadas. Así, la resolución operará como modo de extinguir si aún no se han ejecutado, como ocurre con aquella incumplida del demandante, pero respecto de otras procede la restitución, es en la especie el caso del precio, logrando así una necesaria liquidación económica del contrato. Debe, por ende, distinguirse el momento en que

15 Saleh con Álvarez (2011) Corte Suprema, 13 de junio de 2011, rol 1958-2010.

16 López (2010), p. 508. Se sitúa dicho efecto retroactivo en el artículo 1487 del Código Civil. Abeliuk, en cambio, sólo habla de restitución sin referirse a retroactividad, AвELIuk (2011), pp. 538 y ss. Fueyo, por su parte, alude al efecto ex tunc de la resolución, Fuero (2004), pp. 337 y ss. 
se quebró la reciprocidad, pues ahí queda sin justificación el cumplimiento de la obligación de la parte afectada por el incumplimiento, lo que da lugar a partir de ese momento a las restituciones como un efecto propio a la resolución. Esto permite abandonar la perspectiva que distingue entre contratos que se calificarían a tracto sucesivo o de ejecución instantánea, lo que permitía distinguir si procedía o no un efecto retroactivo, el que se negaba para los supuestos contratos de ejecución a tracto sucesivo. No solo es inoportuna esta distinción, dado que los contratos involucran obligaciones de distinta especie, sino que la restitución opera tanto en contratos con obligaciones a tractos, sucesivas o de ejecución instantánea. Lo relevante es determinar cuándo comienza el período a partir del cual deben aplicarse las restituciones. Mientras perdure la reciprocidad, no hay lugar a restitución alguna, pero una vez quebrada, procede aplicarla. El arrendador, conforme está acreditado, nunca cumplió con su obligación de entrega de la cosa; es decir el incumplimiento fue al inicio y por toda la vida del contrato, nada puede reclamar entonces como prestación recíproca, debiendo restituir el precio como efecto del término del contrato, pues nada dio a cambio, rompiendo el sinalagma". ${ }^{17}$

Lo mismo puede decirse respecto a la indemnización de perjuicios. En el caso de la nulidad, el derecho de la parte afectada para demandar perjuicios estará determinado por la concurrencia de los requisitos de la responsabilidad extracontractual, entre los cuales tomarán especial relevancia la culpa o dolo de la otra parte, no siempre presentes en caso de nulidad. ${ }^{18}$ Es posible advertir una diferencia sustancial en el régimen de daños, pues en el ámbito de la nulidad la configuración de los elementos de la responsabilidad aquiliana serán más difíciles en lo que refiere a la imputación subjetiva por culpa o dolo; en cambio, tratándose de la resolución, atendido lo dispuesto en el artículo 1547 inciso $3^{\circ}$, la culpa se presume, dejando abierta la vía para la indemnización acreditando el vínculo causal y el daño. Asimismo, en general, los perjuicios indemnizables en caso de nulidad no incluyen el lucro cesante. En cambio, en el caso de la resolución, el contratante diligente tiene derecho a que se le indemnicen los perjuicios derivados del incumplimiento (el cual se presume culpable), los cuales serán determinados en base a las reglas de la responsabilidad contractual, para lo cual los términos del contrato que se ha declarado resuelto resultan esenciales, sobre todo considerando la regla de previsibilidad prescrita en el artículo 1558

17 Moena con Quidel (2016), Corte Suprema, 2 de junio de 2016, rol 6528-2015.

18 En el mismo sentido, Pinochet y Concha (2015), pp. 131-132. Distinguiendo según el vicio, Baraona (2007), pp. 67-72. 
del Código Civil. En suma, en el caso de nulidad se indemniza el denominado interés negativo, y en la resolución, el interés positivo.

Si debiéramos concluir acerca de la retroactividad en la nulidad y en la resolución, diremos que en la primera es perfecta, mientras que en la segunda (en caso de aceptarse) es una mera ficción. En la nulidad corresponde olvidar el contrato, retrotrayendo las partes a un estado como si nunca hubieren contratado, mientras que este efecto es imposible en la resolución, debiendo contarse con el contenido contractual dispuesto para el incumplimiento. Así, por ejemplo, mientras la cláusula penal en el contrato nulo desaparece consecutivamente, esa misma garantía pervive en la resolución.

En general, en el derecho uniforme de contratos la resolución carece de efectos retroactivos y sólo opera hacia el futuro, o al menos así pretende presentársele, tanto si se trata de contratos de ejecución instantánea como de ejecución diferida o continua. Así lo estipulan los artículos 7.3.5 PICC, 9:305 PECL y III.- 3: 509 DCFR. ${ }^{19}$ Las eventuales restituciones que deban efectuar las partes no se basan en un (ficticio) efecto retroactivo, sino al contrario, en la existencia de un contrato el cual ha sido extinguido en virtud del incumplimiento de una de las partes y cuyos efectos deben ahora ser corregidos para evitar el enriquecimiento injustificado de uno de los contratantes a costa del otro. Subyace a esta idea que lo que se haya dado o pagado en virtud del contrato resuelto ahora, una vez declarada u operada la resolución carece de causa, pasando a constituir un pago de lo no debido. De ahí la idea de que más que hablar de retroactividad quepa proceder a una liquidación económica del contrato. ${ }^{20}$

Si bien podría pensarse que, en virtud del efecto restitutorio a que da lugar la resolución, la diferencia práctica entre el efecto ex tunc y ex nunc es irrelevante, admitir que la resolución opera hacia el futuro permite explicar mejor varios de sus efectos, particularmente la sobrevivencia de las cláusulas del contrato diseñadas justamente para el incumplimiento, así como los efectos respecto de terceros. La posibilidad que el contratante diligente pueda demandar perjuicios también parece más lógica si se admite que la resolución opera ex nunc.

\footnotetext{
19 Así por ejemplo, por todos, el art. 9:305 de los PECL dispone: "Efectos de la resolución (1) La resolución del contrato libera a ambas partes de la obligación de cumplir y de recibir futuras prestaciones, pero de acuerdo con los artículos 9:306 a 9:308, no afecta a los derechos y obligaciones que se hubieran generado hasta el momento de la resolución. (2) La resolución no afecta para nada a las estipulaciones previstas en el contrato para la solución de conflictos, ni a cualesquiera otras cláusulas que deban surtir efecto incluso tras la resolución".

20 Así se ha señalado que "El contrato no es 'aniquilado' como consecuencia de la resolución, sino que se 'reorienta' para permitir la liquidación de la situación existente entre las partes como consecuencia del incumplimiento", Palazón (2011), p. 444.
} 
Esta es generalmente la solución que se acepta tanto a nivel de derecho continental como en el common law. ${ }^{21}$ Lo cierto es que no existe razón para tratar de una misma manera a la nulidad y a la resolución por incumplimiento frente al pretendido efecto retroactivo. Tal como dijimos, y a pesar de las voces que pretenden una supuesta unificación en lo relativo a los efectos de la nulidad y la resolución, lo cierto es que difieren en su fundamento y en sus consecuencias. Mientras la nulidad acentúa un marcado efecto retroactivo, la resolución deja incólume una parte considerable del contrato atada a los efectos del incumplimiento, ya sea que opere por vía de notificación, con carácter judicial o de pleno derecho en la hipótesis del pacto comisorio calificado.

Así, en el caso de la resolución, las restituciones dejan de entenderse como derivadas de un contrato que nunca tuvo lugar, siendo un efecto o consecuencia del incumplimiento de un contrato válido. Ello permite también resolver cualquier conflicto teórico respecto a la justificación de la sujeción de las indemnizaciones producto de la resolución al régimen de responsabilidad contractual, ya que el contrato se considera existente y capaz de producir efectos, los cuales para este caso derivan de su incumplimiento.

\section{3. ¿Acción o efecto?}

Un segundo problema se refiere a si las restituciones consecutivas a la nulidad o la resolución constituyen un efecto $u$ otorgan una genuina acción para reclamarlas. Dado que la nulidad extrajudicial carece de reconocimiento en Chile, lo que contrasta con la resolución que puede tener un carácter extrajudicial en la hipótesis de resolución convencional, ya sea como pacto comisorio calificado o cláusula resolutoria, tratándose de la nulidad, las restituciones siempre serán un efecto consecutivo a su declaración judicial, sin que exista necesidad que el demandante así lo estipule en su demanda. El mero hecho que opere la nulidad, conforme los artículos 1687 y 1689 dará derecho a las restituciones consecutivas y a la acción reivindicatoria.

En cambio, en el caso de la resolución, atendido que puede operar en forma extrajudicial, por cierto existirá la acción respectiva para exigir las restituciones, la que podrá ejercerse junto a aquella indemnizatoria si fuere procedente. En cambio, si la resolución opera por vía judicial, al ejercerse la acción resolutoria emanada de la condición resolutoria tácita, al igual que en la nulidad las restituciones deberán considerarse un efecto consecutivo a la declaración de

21 Para una sinopsis del derecho comparado en cuanto a los efectos de la resolución, véase Smits (2014), pp. 237-240. 
la nulidad. Un caso relativo a una compraventa de bienes inmuebles, resuelto por la Corte Suprema, se refiere a este asunto. ${ }^{22}$

En dicho caso se incumplió con la obligación de pagar el precio, dándose lugar a la resolución del contrato, pero la Corte de Apelaciones de Santiago revocó la parte en que se ordenaba la restitución de las cuotas pagadas a título de precio, por lo que la demandada se alzó en casación ante la Corte Suprema por infracción de los artículos 1487 y 1875 inciso $2^{\circ}$ del Código Civil, señalando que la restitución constituye un efecto de la resolución sin que haya necesidad de requerirlo en forma expresa.

Conociendo del recurso, la Corte Suprema sostuvo que: "Es evidente que en tal caso deberá restituírsele lo ya pagado, pues en caso contrario habría un enriquecimiento sin causa para el acreedor, ya que por un lado se le restituye la cosa dada o pagada por él, o se inhibe de darla o pagarla, y por el otro, recibe su parte del precio.

Luego, denegar al comprador la devolución de aquella parte del precio pagada con anterioridad a la declaración de resolución del contrato, no resulta acorde a derecho, pues atenta contra este principio y con el de economía procesal, atendido el propio reconocimiento efectuado por el actor, tanto en su libelo como en estrados, de haberse pagado parte del precio de la compraventa, estimando dicha parte como necesaria una solicitud expresa en tal sentido y el inicio de un nuevo proceso; debiendo las partes ser restituidas al mismo estado en que se hallarían si no hubiesen existido las convenciones cuya nulidad se declara, observándose, en las restituciones mutuas que hubiere lugar, las reglas que al efecto prevé el inciso $2^{\circ}$ del artículo 1687 del Código Civil y considerándose al demandado como poseedor de buena fe, sin costas, por estimarse que este último litigó con fundamento plausible".

Lo que puede concluirse de este fallo, y que estimamos correcto, es que no cabe exigir que se ejerza la acción de restitución en caso de acción de resolución o acción de nulidad, siendo un efecto consubstancial a dichas ineficacias que procedan las restituciones si hubo ejecución de las obligaciones.

El problema que se presenta, eso sí, es plantearse qué pasa con el goce del comprador a título de propietario durante el período que media entre la entrega de la cosa y la restitución de la misma. El uso y goce por parte del comprador debiera también considerarse, en términos que cabe plantearse si procede a título de indemnización o en cambio debiera ser a título de restitución por el valor que representa el goce durante ese tiempo. Esto permitiría compensar la

22 Continental Inmobiliaria y Servicios con Dattas Labadie Jean Pierre (2012) Corte Suprema, 30 de enero de 2012, rol 4198-2011. 
parte del precio o lo que corresponda con el goce del comprador que ahora carecería de causa una vez declarada la resolución.

A este respecto, el art. III.- 3:513 del DCFR establece que el deudor que debe restituir debe pagar una suma razonable por el uso que ha hecho de la cosa. Excepcionalmente, si dicho uso ha implicado un deterioro del bien que debe restituirse, el deudor sólo será responsable por dicho deterioro. En otras palabras, se entiende que el valor del uso está incorporado en el de los deterioros. El fundamento de la norma es evitar un doble pago o compensación. Esta es también la norma que se establece en el derecho alemán (BGB, §346(1) y (2) $\left.\mathrm{N}^{\circ} 3\right) .^{23}$

La cuestión presenta algunos temas complejos. La mera posibilidad de poder usar o gozar de algo representa un valor. Si se acepta que quien tuvo la cosa a su disposición debe restituir el valor del uso y goce de la misma, ¿ese valor debe establecerse objetivamente, según el precio de mercado para un uso razonable de la cosa? ¿O incluye también toda ganancia o beneficio que quien detentó la cosa obtuvo con su uso y goce? ${ }^{24}$ Teóricamente incluso podría tratarse de frutos civiles. Esta última alternativa representaría aceptar la restitución de ganancias obtenidas a propósito del incumplimiento de un contrato, cuestión controvertida y cuyo análisis excede el ámbito del presente estudio. Por ello, en principio, parece razonable que en caso de aceptarse que deba restituirse el valor del uso, dicho valor se limite al precio de mercado y no se extienda a las ganancias obtenidas por el deudor con el incumplimiento del contrato. Sin duda en los sistemas continentales las restituciones por provecho encuentran un escaso tratamiento y menos aplicación. Aparte la regla del provecho por dolo ajeno prevista a propósito del dolo incidental y en materia extracontractual, no existe una regla general que involucre el derecho a reclamar el provecho que otro haya obtenido incluso sin culpa.

\section{Las restituciones en los contratos con obligaciones de ejecución instantánea ${ }^{25}$}

Si el contrato en cuanto alguna o algunas de sus obligaciones es de ejecución instantánea, puede ocurrir que ambas partes hayan cumplido, aunque sea en forma parcial, con sus obligaciones correlativas. De ahí que podamos afirmar que las restituciones son un efecto circunstancial o posible de la nulidad y la

\footnotetext{
23 Comentarios oficiales, art. III.- 3:513 DCFR.

24 ZiMMERMANN (2011), p. 580.

25 Técnicamente, lo que cabe clasificar como de ejecución instantánea, diferida o continua son las obligaciones de las partes y no el contrato. En este sentido PeÑalliLlo (2003), pp. 345 y ss.
} 
resolución, mas no obligatorio, en razón que, si nada se ha entregado o no hay servicios o usos que compensar, las partes nada se deben entre sí. Mal podría, en este caso, afirmarse la procedencia de restituciones. Pero el caso que sí nos interesa es aquel justamente en que el vendedor entregó todo o parte de la cosa, y el comprador pagó todo o parte del precio.

En la hipótesis que la restitución recaiga en una cosa, ya sea porque se entregó parte o la totalidad de ella, la regla general en los sistemas legales es que la restitución sea en especie. Así está dispuesto el régimen legal a propósito de las restituciones mutuas contempladas en la regulación de la acción reivindicatoria conforme los artículos 904 y siguientes del Código Civil. El mismo principio recoge el artículo 1487 en relación a la condición resolutoria cumplida y también el artículo 1687 que se remite a las reglas generales que no son otras que aquellas de las prestaciones mutuas.

En consecuencia, el principio consiste en que la restitución de la cosa entregada deberá hacerse, por regla general, en especie. Lo mismo ocurre en los instrumentos supranacionales de derecho de los contratos (arts. 3.2.15(1) y 7.3.6(1) PICC, 4:115 y 9:308 PECL, II.- 7:212 y III.- 3:510 DCFR y 172 de la Propuesta de Normativa Común de Compraventa Europea - CESL). Sólo excepcionalmente puede efectuarse la restitución en valor, no pudiendo ello quedar a elección del comprador. Aceptar la regla contraria significaría que las restituciones mutuas sólo implicarían una compensación entre el precio o la parte del precio que el vendedor debe restituir y el valor de la cosa. Ello además traería como consecuencia que el vendedor se vería forzado a aceptar la retención de la cosa por parte del comprador, siendo que se pretende lo opuesto con la resolución.

En el caso que la restitución en especie sea posible, ella debe hacerse sin considerar eventuales cambios de su valor de mercado. ${ }^{26}$ No corresponde entonces, por vía de restitución, compensar al vendedor por el menor valor de la cosa, ni en el caso contrario, tampoco al comprador si la cosa se ha valorizado. Así ocurre en el evento que se verifique la destrucción parcial de la cosa por caso fortuito o fuerza mayor, lo que constituye una manifestación de la teoría de los riesgos de acuerdo al artículo 1486 del Código Civil. El acreedor recibe la cosa sin derecho a indemnización, lo que se explica porque asume las ventajas y desventajas que padezca la cosa pendiente la entrega siguiendo la regla res perit creditori. Sin embargo, si concurre culpa en la destrucción parcial de la cosa el acreedor puede resolver o aceptar la cosa en el estado que se encuentre más la indemnización de perjuicios (artículo 1486, inciso $2^{\circ}$ ).

Por cierto si la cosa no es una especie o cuerpo cierto, la regla precedente no recibe aplicación, en cuyo caso deberá el comprador restituir una cantidad

26 El art. 2198 establece el mismo principio para el caso de la restitución de cosas fungibles que no sean dinero en el mutuo. 
similar de la misma calidad. Así lo dispone o podemos interpretarlo del artículo 1510 del Código Civil, el que dispone que "La pérdida de algunas cosas del género no extingue la obligación, y el acreedor no puede oponerse a que el deudor las enajene o destruya, mientras subsistan otras para el cumplimiento de lo que debe". El Código Civil no contempla una regla que impida la restitución por equivalente, sobre todo si se trata de cosas genéricas, ni tampoco que pueda restituirse en valor, al menos así se acepta a propósito del usufructo (art. 775) y en el mutuo (art. 2198). Pareciese entonces que no hay obstáculo a admitir la restitución en valor, cuando la restitución en especie es imposible. Por cierto, el art. 1687 no lo prohíbe, y de su texto más bien parece deducirse que la restitución en valor es admisible, ya que para el caso de nulidad, da a las partes derecho "a ser restituidas al mismo estado en que se hallarían si no hubiese existido el acto o contrato nulo", sin especificar si la restitución debe hacerse en especie o en valor cuando aquella es imposible. ${ }^{27}$

Como se dijo, a nivel de derecho uniforme, se acepta excepcionalmente que la restitución pueda hacerse en valor (arts. 3.15.(2) y 7.3.6(2) PICC, arts. 9:307 a 9:309 PECL, art. III.- 3:510 DCFR y art. 173 CESL). Así sucederá por ejemplo cuando es imposible restituir la cosa entregada porque esta se destruyó y el comprador debe soportar el riesgo, o porque la ha transformado o transferido a terceros. Habitualmente, ello también sucederá en el caso de los servicios, y lo mismo si se acepta que debe valorizarse el uso y goce de la cosa. Las normas se aplican no sólo cuando la restitución en especie es imposible, sino también cuando no es apropiada, esto es, cuando dicha restitución implica un gasto o esfuerzo irrazonable para el obligado, que no se encuentra en consonancia con el interés comprometido en el contrato.

El common law tiene una posición particular para el caso que se busque la restitución del valor (benefits) de servicios prestados en virtud de un contrato que se ha resuelto por incumplimiento. Si es la parte cumplidora la que solicita la restitución, en general se concede la restitución quantum meruit por los servicios prestados. La valorización se efectúa tomando en cuenta el beneficio obtenido por quien ha recibido los servicios y no por el precio acordado para la prestación. Sin embargo, dicho precio se considera como la avaluación normal o razonable del beneficio obtenido, recayendo sobre el demandante la carga de probar que el beneficio ha sido mayor para quien recibió los servicios. La razón para ello es que se considera que la acción de restitución es una de enriquecimiento injustificado, y no una de naturaleza contractual. ${ }^{28}$ En cambio, si

27 Thibierge (2009), pp. 555 y ss. La autora plantea su tesis respecto a la influencia de distinguir la especificidad de las nociones de nulidad y responsabilidad y cómo esto repercute en el ámbito de las restituciones.

28 Burrows (2011), pp. 347-352. 
es la parte incumplidora la que solicita la restitución del valor de los servicios prestados, se le deniega dicha posibilidad y debe por tanto soportar la pérdida. Ello puede implicar un enriquecimiento injustificado para quien ha recibido los servicios, por lo que en general se considera una solución insatisfactoria. ${ }^{29}$

El dilema que se enfrenta es si la valorización del bien debe realizarse conforme lo acordado por las partes o al valor de mercado de la cosa al momento de contratar. Pueden plantearse al respecto dos opciones. ${ }^{30}$

Si uno asume la idea de liquidación económica o retroactividad a la época de la celebración del contrato, debiera inclinarse por el valor objetivo sin considerar el acuerdo de las partes. Eso haría compatible la indemnización con la restitución en valor del bien específico de que se trata, logrando así un equilibrio necesario y una liquidación económica apropiada consecutiva a la resolución.

Por otra parte, como ya se indicó, si la cosa existe al tiempo de la restitución, no cabe solicitar compensación alguna por la variación en su valor ocurrida en el tiempo intermedio entre la entrega y la restitución. ${ }^{31}$ El mismo principio debería aplicarse para el caso en que la cosa no exista o se haya deteriorado de tal forma que la restitución deba hacerse en valor. De esta manera, la valorización debería efectuarse en relación con el precio acordado por las partes.

También puede sostenerse que las restituciones mutuas no están sujetas a los límites de la indemnización de perjuicios, en el sentido que no es admisible para el contratante incumplidor alegar que la restitución dejará al contratante que cumplió (o está dispuesto a cumplir) en una mejor situación que si el contrato se hubiera ejecutado ${ }^{32}$. Así por ejemplo sucede en el caso que el comprador demande la restitución del precio pagado por bienes cuyo precio de mercado es menor, al momento de la restitución, que al de la celebración del contrato. En este caso, el incumplimiento del contrato (la no entrega o entrega defectuosa por parte del vendedor) deja al comprador en una mejor situación que el cumplimiento, permitiéndole de alguna manera escapar de un mal negocio. Esto implica que se altera la distribución de riesgos del contrato. Pero ello se puede justificar diciendo que, al haberse resuelto el contrato, la distribución de riesgos acordada por las partes ya no es aplicable. También se puede argumentar que el pago anticipado ha quedado sin causa al no haberse cumplido la contra-

\footnotetext{
29 Sumpter $v$ Hedges [1898] 1 QB 673, y Bolton v Mahadeva [1972] 1 WLR 1009. Véase BuERrows (2011), pp. 357-358.

30 ThiBierge (2009), pp. 678 y ss.

31 Así lo indican expresamente los comentarios oficiales al art. IlI.- 3:510 DCFR (comentario E). Esto no debe confundirse con las reglas aplicables a aumentos, mejoras o deterioros, las cuales son hipótesis diversas a la variación del precio de mercado del bien.
}

32 JAFFEY (2013), p. 437. 
prestación, de manera que corresponde su completa restitución. Asimismo, no permitir al comprador recuperar totalmente el precio implicaría un enriquecimiento injustificado para el vendedor (no cumple y además retiene parte del precio como si el contrato se hubiese ejecutado).

Además, esta aparente injusticia se compensa con la imposibilidad para el comprador de demandar lucro cesante en este caso, ya que la operación de reemplazo no le significará un desembolso adicional al precio originalmente pactado.

Por otra parte, si los bienes tienen un precio de mercado mayor al tiempo de la restitución, el vendedor que ha cumplido también tiene derecho a solicitar la restitución sin tener que compensar ese mayor valor al comprador incumplidor. En este caso, tampoco el vendedor dispondrá del lucro cesante, pero sí podría alegar eventualmente daño emergente, lo cual también será difícil ya que es de suponer que la mayoría de los gastos que le ha implicado la ejecución del contrato estarán incluidos en el precio. Las razones expuestas anteriormente sirven para sustentar esta solución.

En todo caso los problemas vinculados a la restitución son inmensos, lo que impide una claridad absoluta de cómo debemos proceder en su cálculo y fecha de evaluación, quedando en gran medida a discreción de los jueces del fondo. Podemos concluir, eso sí, que lejos de compartir el criterio tradicional de la doctrina y el fallo citado, debiera avanzarse en la restitución en valor para los casos de imposibilidad de restitución de la cosa.

\section{Las restituciones en los contratos con obligaciones de ejecución continua o a tractos}

En los contratos denominados de ejecución diferida y a tractos se suele señalar que la resolución (que habitualmente se denomina en este contexto terminación) carece de efecto retroactivo y no habría lugar a restituciones. Esto, por cierto, contrasta con la nulidad en que siempre podremos afirmar el carácter retroactivo cualquiera sea la naturaleza de las obligaciones.

Sin perjuicio de lo anterior, a propósito de la nulidad de un contrato de arrendamiento, se ha fallado por la Corte Suprema que el efecto retroactivo de la nulidad no puede generar un enriquecimiento injustificado para una u otra parte, indicando la Corte que "se trata de que las partes de alguna manera resulten razonablemente restituidas de manera justa como efecto de sus mutuas prestaciones, sin que se deban producir enriquecimientos injustificados de una a favor de la otra. En el caso de que lo que deba restituirse sea una propiedad por una parte, y dinero por la otra, que es precisamente la situación que se produjo en la controversia que nos ocupa, es interesante advertir que, estando ambas de buena fe, resulta razonable y sensato compensar el uso que la una 
hizo de la propiedad, con la renta que la otra pagó por ella, y que fue el criterio que adoptó la sentencia recurrida".$^{33}$

En materia de resolución, la posición clásica en este asunto aparece en un fallo de la Corte de Apelaciones de San Miguel: ${ }^{34}$.

"Estos sentenciadores concluyen que la acción deducida por el actor no se encuadra en la situación fáctica que sirve de fundamento a su acción, puesto que la naturaleza jurídica del contrato celebrado entre las partes, como el hecho que éste ya se ejecutó en su integridad, no permite retrotraer los efectos del contrato al estado anterior de su ejecución, como lo ordena la condición resolutoria tácita cumplida y, en consecuencia, lo procedente es resarcir los daños que se hayan producido".

En otros términos, no habría restitución posible en los contratos en que una de las partes haya gozado de un bien, sino que sólo cabría otorgar indemnización de perjuicios. No podría "restituirse el goce de la cosa".

Este esquema coloca a la restitución en especie como una regla absoluta. Si bien cuando la cosa existe corresponde que recaiga la restitución sobre la misma, con los problemas que genera su deterioro o mejoras, es distinto cuando existe imposibilidad de llevarlo a cabo.

Asimismo, parece adecuado aplicar la regla no sólo a los contratos de ejecución continua en que se presta un servicio o se confiere el goce de una cosa, sino también a aquellos en que las obligaciones se cumplen por parcialidades. En este caso, tampoco procedería la restitución respecto de aquellas parcialidades de la obligación que se han cumplido recíprocamente por los contratantes. Solo cuando no exista o deje de existir un equilibrio entre las prestaciones ejecutadas por las partes, procedería la restitución para el contratante cumplidor (III.- 3:511(1) DCFR).

Así, por ejemplo, si el vendedor cumple con tres de diez entregas pactadas, las cuales a su vez han sido pagadas por el comprador, no procede la restitución de tales mercaderías ni de la parte del precio pagada por ellas. Sin embargo, si por ejemplo el comprador hubiese pagado el precio total por adelantado, podrá pedir la restitución de la cantidad equivalente a las entregas no realizadas.

Un análisis equivalente cabe realizar en los casos en que no pueda restituirse el goce de la cosa, ipuede o procede su restitución en valor? No son pocos los casos en que la restitución en naturaleza deviene imposible o por la naturaleza de la prestación siempre lo fue, en caso de prestación de un servicio o el goce de un bien.

33 Feyerabend y otro con Bravo Vergara (2014), Corte Suprema, 20 de enero de 2014, rol 5818-13.

34 Díaz Zamora, Ma Teresa con Blanco Herrera, Ricardo (2009) Corte de Apelaciones de San Miguel, $N^{\circ}$ identificador CL/JUR/2565/2009. 
Parece sensato para todos estos casos pensar en la restitución en valor. La contrapartida dineraria, lo que plantea otro tipo de problemas, por ejemplo, en relación a la determinación del valor. Lo señalado anteriormente en cuanto a las restituciones en valor procede también aquí.

Excepcionalmente, aun cuando se trate de un contrato de ejecución continua o a tractos, si aquella parte de la obligación que se ha ejecutado carece o sólo tiene un valor mínimo para el acreedor, de manera que no satisface de manera alguna el interés que aquel tuvo al contratar, podrá restituir lo ejecutado por el deudor y a su vez exigir que se le restituya aquella parte de su propia prestación que ya haya cumplido (art. 9:306 PECL, III.- 3:511(2) DCFR).

En resumen, en cuanto a los contratos con obligaciones de ejecución sucesiva más bien debiera pensarse en una regla que impidiera la restitución, pero sólo circunscrita al período en que hubo equilibrio en las prestaciones, las que se compensarían si responden a valores correspondientes, debiendo proceder la restitución en valor después de dicha ruptura.

\section{Frutos y otros beneficios}

Conforme ya señalamos, las restituciones consecutivas a la nulidad quedan gobernadas por las prestaciones mutuas reguladas a propósito de la acción reivindicatoria. En cambio, aquellas de la resolución son normadas por reglas particulares, que si bien están previstas a propósito de la condición, han sido aplicadas en forma extensiva a la resolución por incumplimiento.

Un terreno en que opera la diferencia entre la nulidad y la resolución es la restitución de los frutos. Mientras la nulidad somete la restitución a la condición de mala fe del deudor, que suele fijarse en el momento de la notificación de la demanda, ${ }^{35}$ la resolución veda toda restitución de los mismos, bajo la idea que eso impulsa una actitud más cuidadosa del deudor respecto del objeto debido, impidiendo que deje la cosa en estado de infructífera (artículo 1488). ${ }^{36}$

En cambio, en la compraventa, procede la restitución total de los frutos si no hubo pago alguno del precio o en proporción a la parte que no fue pagada (artículo 1875). La distinción que hace la norma es anómala, ya que el comprador siempre tiene derecho a que se le restituya la parte que hubiera pagado

\footnotetext{
35 La distinción entre poseedor de buena y de mala fe en relación con la restitución de frutos, implica una penalización a la conducta del poseedor vencido, en cuanto a si conocía o no que la cosa era ajena. Lo cierto es que, en estricto rigor, la pertinencia de esta distinción puede discutirse cuando se aplica al ámbito de la nulidad contractual, en la cual el efecto retroactivo debiese implicar la restitución de frutos sin distinguir la buena o mala fe del poseedor, el cual en todo caso (aplicando los efectos de la retroactividad) ha carecido siempre de título para retenerlos.

36 Contardo (2015), pp. 155 y ss, en particular p. 162 y 163. En el mismo sentido Meza (2007), p. 40.
} 
del precio (inciso $2^{\circ}$ del mismo artículo). Ello parece injusto para el vendedor, quien tendrá que aceptar, en caso de haberse pagado una parte del precio, una restitución menor de frutos, debiendo, sin embargo, restituir de igual forma la parte del precio pagado al comprador.

Tanto la regla del artículo 1488 como la del 1875 son insatisfactorias, especialmente desde la perspectiva de la resolución contractual por incumplimiento. Si bien la primera puede tener algún sentido en el caso de una condición resolutoria ordinaria, no se justifica en el caso del incumplimiento de un contrato. ¿Cuál es la razón para que quien recibe una cosa y no cumple con su obligación correlativa tenga derecho a retener los frutos de la misma, más aún si a su vez puede pedir la restitución de la parte del precio que eventualmente hubiese pagado? No hay razones ligadas a la protección de la apariencia o de terceros que lo justifiquen. La norma del artículo 1875 se hace en parte cargo de la objeción, pero nuevamente falla al permitir la retención de frutos en caso de pago parcial del precio ${ }^{37}$.

A la luz de lo anterior, la diferencia no se justifica y debiera unificarse el criterio en términos que hubiera restitución de los frutos. Así lo hemos propuesto en la redacción de los Principios Latinoamericanos de Derecho de los Contratos (PLDC). La regla también es la que sigue la CVCIM (art. 84) y el DCFR (art. III.- 3:510(5)). Al contrario, los PICC expresamente no regulan la materia en su art. 7.3.6. La cuestión fue ampliamente debatida y finalmente se decidió no establecer una regla al respecto, debido principalmente a la complejidad que en materias comerciales implica establecer los beneficios (entendidos en sentido amplio) que las partes han obtenido en el tiempo intermedio a la anulación o resolución del contrato. Se estimó en este sentido que una regla de restitución de frutos, o más generalmente, de beneficios, tendría efectos adversos en los costos y duración de la litigación, lo cual fue confirmado por la constatación que, en la práctica, las partes usualmente se conforman con la restitución de lo ejecutado en virtud del contrato y buscan la compensación de los beneficios perdidos por el incumplimiento a través de la indemnización de perjuicios ${ }^{38}$. Este es un tema que se relaciona con las indemnizaciones que pueden acompañar a la restitución, según se dirá más adelante.

Es interesante destacar que la Convención de Viena sobre Compraventa Internacional de Mercaderías (CVCIM) establece de manera amplia la restitución de frutos y beneficios en caso de resolución. El art. 84 señala que el vendedor debe restituir el precio con los intereses devengados desde la fecha del

37 Como puede apreciarse, esta es otra materia donde no parece conveniente asimilar la resolución contractual por incumplimiento a la condición resolutoria.

38 ZimmermanN (2011), pp. 582-583. 
pago, y por su parte, el comprador deberá restituir las mercaderías con todos los beneficios que se hayan obtenido de ellas ${ }^{39}$. Se entiende que la restitución de beneficios debe hacerse en dinero, de manera que las restituciones mutuas pueden compensarse ${ }^{40}$.

El texto del art. 84 ha sido interpretado en el sentido que la restitución por el comprador de todos los beneficios que haya obtenido de los bienes incluye no sólo los frutos y productos en su sentido tradicional, sino también cualquier otra ventaja económica que haya obtenido, por ejemplo, las ganancias obtenidas por la reventa de los bienes, los pagos que haya obtenido de terceros por concepto de licencias, etc., e incluso el valor del uso que haya hecho de los bienes durante el tiempo que estuvieron bajo su poder ${ }^{41}$. Por cierto, si el uso ha implicado la trasformación o destrucción de los bienes, deberá abonar el valor de los mismos más el valor del uso.

Debe precisarse que para el caso de ganancias obtenidas con las mercaderías (por reventa, licenciamiento, etc.) se ha planteado que el punto de referencia para la restitución debe ser el indicado en el art. 82(2), es decir, una ganancia hecha en el curso normal de los negocios. Ello implica que el comprador deberá restituir la ganancia que haya obtenido bajo condiciones normales de mercado. Si en virtud de sus atributos personales (por ejemplo, su capacidad de negociación) ha obtenido una ganancia superior, no estaría obligado a restituir la totalidad de las ganancias y podría retener la diferencia. El fundamento sería evitar un enriquecimiento injustificado para el vendedor. Sin embargo, también se ha planteado que la norma no distingue y que por tanto, cuando el contrato se resuelve por incumplimiento del comprador, este debería restituir al vendedor todas las ganancias obtenidas con los bienes ${ }^{42}$.

Esta concepción amplia de la restitución de beneficios implica como contrapartida que deberán descontarse de ellos los gastos incurridos en los bienes, no sólo de acuerdo a la tradicional distinción entre mejoras necesarias, útiles y voluptuarias, sino también aquellos costos incurridos por el comprador para

\footnotetext{
39 Debe recordarse que el art. 907 del CC incluye dentro de los frutos a restituir, "no solamente los percibidos sino los que el dueño hubiera podido percibir con mediana inteligencia y actividad, teniendo la cosa en su poder." Ello implica que, por ejemplo, el vendedor deberá restituir el precio no solo reajustado sino también con intereses corrientes. Una norma similar se encuentra en el BGB, §347 I 1.

40 Fountoulakis (2010), p. 1133.

41 FOUNTOULAKIS (2010), pp. 1138-1139.

42 Fountoulakis (2010), p. 1144. Hay que también tener presente que en algunos ordenamientos jurídicos se admite excepcionalmente la restitución de ganancias obtenidas a través de un ilícito, incluyendo los incumplimientos contractuales. Así sucede por ejemplo en el common law (A-G v Blake, [2001] 1 AC 268; y Experience Hendrix LLC v PPX Enterprises Inc [2003] 1 All ER (Comm) 830). Véase en general a este respecto, VIRGO (2006), pp. 478-497.
} 
efectos de obtener un beneficio o ganancia con los mismos (por ejemplo, gastos de marketing o de capacitación de personal).

\section{La indemnización con las restituciones}

Un aspecto en que difieren de manera prístina la nulidad y la resolución es en el ámbito de los perjuicios que correspondería indemnizar. Tratándose de la resolución del contrato nos vamos a situar en la responsabilidad contractual. Los daños indemnizables sólo pueden prosperar si se cumple con las condiciones de la responsabilidad contractual, lo que en términos clásicos corresponde al incumplimiento, la culpa, la constitución en mora del deudor, la causalidad y el daño mismo. Se trata de un régimen legal construido a partir de los artículos 1545 y siguientes del Código Civil.

En cambio, si hay nulidad, sobre todo en el caso de error, la hipótesis de indemnización suele ser escasa y aun más se rige por el régimen de responsabilidad extracontractual, conforme los artículos 2314 y siguientes del Código Civil. ${ }^{43}$

Retomando el caso de la sal. Si se hubiere incoado la acción de nulidad por error, como lo sugirió la Corte Suprema, los perjuicios sólo podrían haberse demandado según el régimen extracontractual, debiéndose probar la culpa, la causalidad y el daño. En cambio, en sede de resolución, su sola configuración dejaría al comprador en una posición bastante cómoda para reclamar los perjuicios, al establecerse el incumplimiento, el que se presume culpable según el artículo 1547 inciso $3^{\circ}$ del Código Civil.

Dicha compatibilidad involucra un régimen diverso, pero lo que más interesa, en el ámbito de la resolución, es su compatibilidad y forma de operar. Como afirmamos, la restitución es un efecto de la resolución o la nulidad, sin que exista necesidad de culpa, de hecho procede a favor de ambos, aun del culpable. ${ }^{44}$ Otra diferencia fundamental radica en la necesidad de un daño para que proceda la indemnización, lo que es ajeno a las restituciones. Asimismo, en el caso de la restitución, no existe para las partes un deber de mitigar el daño,

\footnotetext{
43 La doctrina nacional en general es acorde con la naturaleza extracontractual de la indemnización de perjuicios derivada de la nulidad. Sin embargo, Zuloaga (2006) ha sostenido que trataría de una responsabilidad sujeta a un régimen distinto al contractual y extracontractual, en el cual existiría un factor de imputación objetivo, constituido por la buena fe precontractual. Por su parte, BARAONA (2007), p. 76. Si bien se inclina por el carácter extracontractual, señala que "se trata de una responsabilidad peculiar...en cuanto supone la ruptura de una expectativa o confianza que supera el mero contacto social, del cual deriva un tratamiento específico".

44 En contra, PINOCHET y CONCHA (2015), pp. 146-150, quienes afirman que las prestaciones que el poseedor vencido debe efectuar en virtud de los arts. 906 y 907 tienen carácter indemnizatorio. Sin embargo, no deben confundirse los daños que sufre la cosa que se restituye con los daños derivados de la nulidad del contrato que se deja sin efecto.
} 
como sucede cuando se pretenden demandar perjuicios, por ejemplo, a través de una operación de reemplazo.

A continuación, por su evidente interés práctico, se analizará en mayor detalle la relación entre las restituciones y la indemnización de perjuicios, ya sea en caso de nulidad o de resolución.

\subsection{Nulidad e indemnización de perjuicios}

La doctrina nacional en general está de acuerdo en aceptar la posibilidad de ejercer conjuntamente las acciones de nulidad y de perjuicios, siempre que, tal como se ha señalado, se cumplan los requisitos de una y otra. Ambas acciones son entonces compatibles, pero independientes. ${ }^{45}$

En relación con los daños indemnizables, en general se acepta que, en caso de nulidad, sean aquellos que dejen al contratante perjudicado o inocente en la posición que tendría si el contrato no se hubiese celebrado, esto es, el denominado interés negativo.

El mencionado interés negativo cubre por ejemplo los gastos incurridos en la negociación y celebración del contrato nulo y los daños derivados de su ejecución, por ejemplo, los causados en el patrimonio del deudor por los bienes entregados fraudulenta o erróneamente.

La no indemnización del interés positivo, es decir, aquel que dejaría al contratante perjudicado como si el contrato se hubiese ejecutado correctamente, implica descartar el lucro cesante o ganancias que se hubiesen obtenido con dicho cumplimiento. Ello no implica necesariamente descartar la indemnización de todo tipo de lucro cesante, pero sólo será indemnizable aquel que deriva del hecho de no haberse celebrado un contrato sustituto, en virtud de la confianza que tenía la parte perjudicada en la ejecución del que fue declarado nulo ${ }^{46}$.

Al contrario del Código Civil chileno que no contempla norma expresa al respecto ${ }^{47}$, los instrumentos de derecho uniforme admiten la indemnización de perjuicios para el caso de nulidad. Así lo establecen los arts. 3.2.16 PICC, 4:117 PECL, II.- 7:214 DCFR y 55 CESL. Estas normas establecen como requisitos para demandar perjuicios que la otra parte supiese o debiese saber del vicio que afectaba el contrato (una especie de culpa particular) y que el contratante afectado haya estado de buena fe, es decir, no haya conocido ni debido conocer el vicio que afectaba al contrato.

\footnotetext{
45 Referencias a la doctrina nacional en PinOCHet y Concha (2015), pp. 131-135.

46 Barros (2006), p. 1013.

47 El art. 1687 se refiere sólo a las restituciones mutuas, y el art. 1458 menciona la acción de perjuicios para el caso que exista dolo.
} 
Un aspecto interesante es que los mencionados artículos además conceden la acción de perjuicios a la parte que tenía derecho a demandar o declarar la nulidad, aunque en definitiva ella opte por ratificar el contrato nulo. En este caso los daños se limitan a aquellos derivados particularmente de la causal de nulidad (por ejemplo, el costo de adaptar el proceso de producción o comercialización a los bienes entregados erróneamente), pero no a todos aquellos que significarían dejar al contratante en la misma posición que tendría si el contrato no se hubiese celebrado, ya que en definitiva la parte afectada ha optado por la ejecución del contrato y no por su nulidad.

\subsection{Resolución e indemnización de perjuicios}

No hay duda en términos legales ni de doctrina que la resolución es compatible con la indemnización de perjuicios. Así lo establece expresamente el artículo 1489. Asimismo, y aunque parece obvio, debe tenerse presente que la resolución es incompatible con el cumplimiento forzado. Sin embargo, ello es relevante para entender las ideas que se expresan a continuación.

Cuando el acreedor opta por la resolución, está optando por poner término al contrato y no cumplir su propia prestación. Si ya la ha cumplido en todo o parte, podrá obtener la restitución que corresponda. Al mismo tiempo, renuncia también a obtener la prestación que se le debía. Así, el vendedor que resuelve no podrá exigir la restitución de la cosa y el pago del precio; y el comprador, en la misma situación, no podrá exigir la restitución del precio y la entrega de la cosa. Todo esto parece obvio, pero usualmente no se menciona o considera al analizar los perjuicios que podría demandar el contratante si resuelve u obtiene la resolución.

Así, para la determinación de los perjuicios que pueden demandarse en caso de resolución, se ha planteado que debe considerarse que la finalidad de la resolución es dejar a las partes en una situación similar a la que se encontrarían si el contrato no se hubiese celebrado, y no en una como si el contrato se hubiese cumplido adecuadamente, pues justamente a ello se renunció al optar por la resolución ${ }^{48}$.

En base a lo anterior, y a la mencionada incompatibilidad entre cumplimiento y resolución, se ha estimado que la indemnización de perjuicios de la parte que resuelve el contrato debería estar determinada por la satisfacción del denominado "interés negativo", como se dijo, aquel que pretende colocar a dicha parte en una situación patrimonial similar a la que hubiese tenido si el contrato no se hubiere celebrado. De esta manera, debería excluirse para

48 Llamas (1999), p. 263. 
estos casos la función de la indemnización de perjuicios como cumplimiento por equivalencia, ya que ello supondría aceptar (por un medio indirecto) que quien resuelve el contrato, y por tanto se excusa legítimamente de cumplirlo, a su vez pueda obtener el cumplimiento (por equivalente) de la contraprestación debida ${ }^{49}$.

Se trataría entonces de resarcir los daños que se han sufrido como consecuencia de la frustración de la confianza que la parte perjudicada tenía en la celebración del contrato, también conocidos en el common law como "reliance damages".

Se agrega que esta interpretación en nada contraviene el derecho del afectado a demandar tanto el daño emergente como el lucro cesante, según lo prescribe el artículo 1556, pero ellos deberán establecerse en relación con el interés efectivamente afectado, que como se dijo, es el interés negativo o de confianza. Se trata entonces de daños derivados de la resolución del contrato y no de su falta de cumplimiento ${ }^{50}$.

Sin embargo, la limitación de la indemnización al interés negativo no parece conveniente si se pretende proteger adecuadamente los intereses del contratante cumplidor. Hay que recordar que la retroactividad de la resolución es discutida y que, en todo caso, el contrato existió y al menos potencialmente, produjo o pudo producir efectos en los cuales el contratante diligente confió y por tanto actuó en consecuencia. Esta confianza fue defraudada por el incumplimiento imputable de la otra parte y no por un vicio intrínseco al contrato como en el caso de la nulidad. No cabe por tanto confundir restitución con indemnización, ambos conceptos son compatibles y tienen por fin último evitar que el contratante diligente se vea perjudicado por el incumplimiento de su contraparte.

En este sentido, los PICC dan derecho al acreedor a la reparación integral de los daños y perjuicios causados por el incumplimiento, incluyendo tanto las pérdidas (daño emergente) como las ganancias de las que fue privado o lucro cesante (art. 7.4.2). Siguiendo la misma idea, los arts. 9:502 de los PECL, III.- 3:702 del DCFR y 160 CESL establecen, de manera expresa que "El cálculo de la indemnización de daños y perjuicios se hará de forma que se coloque al perjudicado en una posición lo más próxima posible a la que hubiera disfrutado de haberse ejecutado correctamente el contrato". Queda claro entonces que es la medida del interés positivo la que se considera para el cálculo de las indemnizaciones, o en términos del common law, el denominado expectation interest. En definitiva, lo relevante será que se establezca el nexo causal entre

49 Llamas (1999), pp. 264-265.

50 Llamas (1999), p. 265. 
el incumplimiento y los perjuicios, ya sea por concepto de daño emergente como de lucro cesante.

\section{Los acuerdos de las partes}

En esta materia pueden presentarse diferencias entre la nulidad y la resolución. Además, a mayor libertad de las partes para fijar los efectos de la resolución, menos sustento para la retroactividad.

En general, se estima que las normas que rigen la nulidad son de orden público, de modo que son imperativas para las partes y no pueden estas modificarlas por mutuo acuerdo. Ello se extiende no solo a los requisitos aplicables a los supuestos de nulidad sino también a los efectos de la misma.

En el derecho uniforme, los arts. 3.1.14 PICC, 4:118 PECL, II.- 7:215 DCFR y 56 CESL adoptan la regla general antedicha, con excepción del caso del error, en el cual se acepta que las partes modifiquen las normas legales, acordando restringir o excluir los remedios aplicables, siempre que ello no sea contrario a la buena fe o a la lealtad comercial. La excepción se explica ya que la determinación del error capaz de anular el contrato implica a su vez la determinación de los riesgos que las partes han asumido al contratar, riesgos que pueden ser distribuidos (dentro de los límites de la buena fe) libremente por los contratantes. Por cierto, si el error ha sido causado intencionalmente por la contraparte, puede ser constitutivo de dolo y, por tanto, se vuelve a la regla general ${ }^{51}$. Asimismo, nada impide que con posterioridad a la declaración de nulidad las partes renuncien total o parcialmente a los derechos que para ellas han nacido.

En el caso de la resolución, la norma general en materia de incumplimiento es que las partes puedan acordar libremente los efectos y extensión de su responsabilidad, con los sabidos límites del dolo y la culpa grave. Habitualmente estas cláusulas incluyen aquellas que determinan las categorías de perjuicios por los que responderán las partes, fijan un límite máximo para la indemnización, establecen ciertos supuestos especiales de incumplimiento, alteran la carga de la prueba, etc. En Chile, tradicionalmente el fundamento de texto para admitir la validez de estas cláusulas es el inciso final del art. 1547.

En el derecho uniforme, las cláusulas restrictivas o exoneratorias de responsabilidad son en principio válidas, salvo que sean contrarias a la buena fe $o$ manifiestamente desleal invocarlas (arts. 7.1.6 PICC, 8:109 PECL y III.- 3:105 DCFR).

No hay duda que con las limitaciones antedichas, las partes pueden modificar las reglas sobre indemnización de perjuicios. Sin embargo, la cuestión no

51 Si se acepta la asimilación de la culpa grave al dolo, el error causado por culpa grave de la contraparte tampoco puede ser excluido o modificado. 
es tan clara en lo relativo a las restituciones derivadas de la resolución. Debe recordarse que uno de los fundamentos de las restituciones mutuas es evitar el enriquecimiento injustificado de una parte a costa de la otra. Nuevamente, debe ser la buena fe la medida para evaluar la validez de estas estipulaciones. Una cláusula que dispusiese, por ejemplo, que en caso de resolución solo una de las partes estará obligada a restituir y la otra no, podría considerarse contraria a la buena fe. Sin embargo, una cláusula que ponga de cargo de quien debe restituir los costos que razonablemente se incurran en dicha restitución, puede considerarse en principio válida.

\section{Los riesgos}

Un aspecto importante a determinar, especialmente en la compraventa, es quién debe asumir los riesgos del deterioro o destrucción de la cosa entregada. Para la nulidad, parece claro que el Código Civil asigna los riesgos al dueño, esto es, a quien debe restituirse la cosa por haberse declarado el contrato nulo (arts. 1687 y 906).

En el caso de la resolución, la respuesta es menos clara. Ya hemos dicho que el artículo 1486 puede entenderse aplicable a la condición resolutoria ordinaria y no a la resolución por incumplimiento del art. 1489. El simple hecho que se conceda al acreedor condicional el derecho a "rescindir" (resolver) el contrato en caso que la cosa haya sufrido deterioros o disminuciones imputables al deudor, permite deducir lógicamente que la norma se refiere a un caso diverso al de la resolución por incumplimiento. ¿Cómo podría resolverse un contrato (por deterioro o disminución culpable de la cosa a restituir) que ya se encuentra resuelto (por incumplimiento)? Por otra parte, el art. 1487 sólo señala que, cumplida la condición resolutoria, deberá restituirse lo que se haya recibido bajo tal condición, sin especificar cuál de las partes asume los riesgos.

En particular para la compraventa, el artículo 1862 inciso primero expresamente pone de cargo del comprador el riesgo de la cosa afectada por un vicio redhibitorio, ya que, en caso de destrucción de la cosa, sólo puede pedir la rebaja del precio y no la restitución total del mismo. El CC se aparta aquí de la regla romana "mortuus redhibetur", que para el caso de la muerte del esclavo o animal defectuoso establecía una ficción que permitía al comprador demandar la restitución del precio pagado "como si el esclavo o animal estuviese vivo". Ello implicaba que el riesgo recaía sobre el vendedor. ${ }^{52} \mathrm{El}$ inciso segundo de

52 ZimmermanN (1996), pp. 330-334, que señala que no hay una explicación satisfactoria para la adopción de dicha regla por los juristas romanos. 
la norma citada establece una excepción cuando la cosa perece por un vicio inherente a ella, caso en que el riesgo vuelve al vendedor ${ }^{53}$.

En caso de no pago del precio, el art. 1875 establece que para el abono de los deterioros al vendedor, se considerará al comprador como poseedor de mala fe, lo que podría implicar que "es responsable de los deterioros que por su hecho o culpa ha sufrido la cosa" (artículo 906 inc. $1^{\circ}$ ). Así, el riesgo recaería sobre el vendedor, ya que, en caso de deterioro o extinción de la cosa por caso fortuito, no podría pedir compensación alguna, viéndose obligado por su parte, a restituir la parte que se hubiese pagado del precio. Si ello es así, lo más conveniente para él será no pedir la resolución del contrato, sino el cumplimiento forzado del mismo, a través del cual podrá obtener el pago del precio, pero no por ejemplo el mayor valor que el objeto hubiese tenido al momento de la restitución.

En el contrato de compraventa, el imponer los riesgos al vendedor cumplidor, produce una situación de desequilibrio, ya que para él es imposible que el objeto de su obligación de restituir (dinero) se extinga. Por ello parece mejor adoptar una regla como la del artículo 1862, que pone el riesgo de cargo del comprador. Esta es la solución que han adoptado los PICC, tanto para la nulidad (art. 3.2.15(2)) como para la resolución (art. 7.3.6(2)). La justificación última está dada por hacer responsable del objeto a quien lo tiene bajo su esfera de influencia y control. Así, es el comprador quien se ha aprovechado o ha podido aprovecharse del bien, y no hay razón para que la nulidad o resolución del contrato haga que el riesgo de eventos ocurridos después de la celebración del mismo (mientras la cosa se encuentra en poder del comprador) "retorne" al vendedor ${ }^{54}$.

La CVCIM por su parte pone el riesgo de cargo del vendedor cuando ha sido este quien ha incumplido, por ejemplo, entregando bienes defectuosos o no conformes (art. 82). Se entiende que la regla se aplica también en el caso que los bienes se destruyan a causa de un vicio inherente a los mismos ${ }^{55}$. Si por el contrario, ha sido el comprador quien ha incumplido el contrato, él deberá soportar la pérdida de la cosa vendida ${ }^{56}$. De manera similar, los PLDC adoptan una posición que podría decirse sanciona al contratante incumplidor con los riesgos de la destrucción de la cosa. Así, el comprador que ha pagado el precio, pero que ha recibido una cosa no conforme o defectuosa y decide resolver el contrato, resulta excusado de restituir el valor de la misma si esta se destruye fortuitamente, aun cuando conserva el derecho a la restitución del precio. $\mathrm{Si}$

\footnotetext{
53 La misma regla se establece en el art. 1647 del Code Civil y 1492 (3) del Codice Civile.

54 ZiMMERMANN (2011), p. 573.

55 Fountoulakis (2010), p. 1119.

56 Se aplican para este caso las reglas contenidas en los arts. 66 a 69.
} 
bien esta solución parece justa, puede objetarse que teóricamente implica que el comprador ha quedado en una mejor situación que si hubiese recibido una cosa conforme al contrato y esta se hubiera destruido por caso fortuito, situación en la cual sin duda el riesgo lo debe soportar él (res perit domino).

\section{Conclusión}

Respecto a la nulidad, no cabe duda que debe mantenerse su efecto retroactivo absoluto, siendo sólo discutible si el régimen aplicable de las prestaciones mutuas resulta apropiado. La pregunta que surge es si no podrían aplicarse los mismos efectos entre las partes para la nulidad y la resolución. Parece que la retroactividad absoluta no es el efecto más adecuado en materia de resolución, ni tampoco es una consecuencia necesaria con los textos vigentes.

Como regla general, las restituciones deberán efectuarse en especie, pero si ello no es posible, por la naturaleza de la obligación, porque las cosas han perecido o porque resulta excesivamente oneroso, debe admitirse también la restitución en valor. El uso de la cosa en el tiempo intermedio entre la celebración del contrato y la nulidad o la resolución debe también valorizarse, formando parte de las restituciones y no necesariamente de la indemnización de perjuicios.

Asimismo, en cuanto a frutos y riesgos, las reglas al respecto debiesen proteger a la parte inocente, de manera que no se vea perjudicada por la nulidad o la resolución provocada por la contraparte.

En suma, si hubiere que proponer una reglamentación de las restituciones, debiera tomarse en cuenta aquella que hemos propuesto para los PLDC tanto para la nulidad como para la resolución.

\section{Efectos de la nulidad}

(1) La nulidad producirá la extinción del contrato.

(2) Anulado el contrato, los contratantes deberán restituirse recíprocamente las prestaciones que hubieran recibido en virtud del mismo. Si la devolución en especie no es posible, deberá restituirse su valor.

\section{De los efectos de la resolución}

La resolución extingue los efectos del contrato. Así y todo, no afecta las cláusulas que las partes hayan previsto para la solución de controversias, las relativas al incumplimiento mismo o cualquier otra cláusula destinada a surtir efecto aun después de la resolución del contrato.

\section{Efectos restitutorios}

(1) Resuelto el contrato, deberán restituirse las prestaciones ya ejecutadas, junto con los frutos percibidos, de manera simultánea o dentro del término que fijen las partes o, en su defecto, el juez. 
(2) Las prestaciones ejecutadas que hayan sido útiles y equivalentes, no darán lugar a restitución. La utilidad se apreciará conforme a la finalidad del contrato.

(3) Si las prestaciones ejecutadas no fueron útiles, se estará a lo dispuesto en el numeral $1^{\circ}$.

(4) La restitución queda limitada al valor de la diferencia, si las prestaciones no son equivalentes.

\section{Imposibilidad de restitución}

(1) Para el caso que no sea posible la restitución, habrá derecho al valor de la prestación fijado al momento de la imposibilidad.

(2) Las partes podrán optar entre lo dispuesto en el numeral anterior o exigir a la otra la cesión de los derechos o acciones que tuviere en contra de terceros.

\section{BiBLIOGRAFÍA CITADA}

Abeliuk MANASEVICH, René (2011): Las obligaciones, 5a edición actualizada (Santiago, Editorial Jurídica de Chile), tomo I.

AlCAlde Silva, Jaime y Vives MARTENS, Álvaro (inédito): “Los efectos de la resolución por incumplimiento en el derecho chileno".

AlesSANDRI BesA, Arturo (2011): La nulidad y la rescisión en el Derecho Civil chileno, $3^{a}$ edición reimpresión (Santiago, Editorial Jurídica de Chile).

BaraOnA, J. (2007): "Nulidad e indemnización de daños y perjuicios", en: Fábrega, H. (editor), Estudios jurídicos en homenaje a los profesores Fernando Fueyo Laneri, Avelino León Hurtado, Francisco Merino Scheihing, Fernando Mujica Bezanilla, Hugo Rosende Subiabre (Santiago, Universidad del Desarrollo), pp. 59-77.

BarRientos Camus, Francisca (2010): "La responsabilidad civil del fabricante bajo el artículo 23 de la Ley de Protección de los Derechos de los Consumidores y su relación con la responsabilidad civil del vendedor", en: Revista Chilena de Derecho Privado (No 14), pp. 109-158.

Barros Bourie, Enrique (2006): Tratado de responsabilidad extracontractual (Santiago, Editorial Jurídica de Chile).

BéCAR Labraña, Emilio (2010): "Revisión crítica de la retroactividad como factor operativo de la resolución del contrato: Algunas perspectivas de reforma para el derecho chileno", en: Derecho y Humanidades (Vol. 2, № 2), pp. 133-152.

Benabant, A. (2008): "La révision du passé entre les parties", en: RDC, pp. 15-24. Burrows, Andrew (2011): The Law of Restitution, $3^{\text {a }}$ edición (Oxford, OUP).

Contardo González, Juan (2011): "Los criterios de interés contractual positivo y negativo en la indemnización de perjuicios derivada de resolución 
contractual", en: Revista de Derecho, Universidad Católica del Norte (Vol. 18, № 1), pp. 85-118.

ContaRdo GonzÁlez, Juan (2015): Indemnización y resolución por incumplimiento (Santiago, Thomson Reuters).

Corral Talciani, Hernán (2006): "La responsabilidad por incumplimiento y por productos peligrosos en la Ley de Protección de los Derechos de los Consumidores", en: Baraona, Jorge y Lagos, Osvaldo (editores), La protección de los derechos de los consumidores en Chile. Aspectos sustantivos y procesales luego de la reforma contenida en la Ley No 19.955 de 2004 (Santiago, Universidad de los Andes, Cuadernos de Extensión Jurídica No 12), pp. 95-110.

De La MAZA, Íñigo (2012): "El régimen de los cumplimientos defectuosos en la compraventa", en: Revista Chilena de Derecho (Vol. 39, № 3), pp. 629-663.

De La MAZA, Íñigo y VIDAL, Álvaro (2014): “Propósito práctico, incumplimiento contractual y remedios del acreedor: Con ocasión de tres recientes sentencias de la Corte Suprema", en: Revista lus et Praxis (Vol. 20, № 1), pp. 15-37.

Díez-Picazo et al. (2002): Los principios de derecho europeo de contratos (Madrid, Civitas).

Fountoulakis, Christiana (2010): "Effects of Avoidance", en: Schwenzer, Ingeborg (editor), Commentary on the UN Convention on the International Sale of Goods (CISG) (Oxford, OUP), pp. 1095-1145.

FueYo LANerl, Fernando (2004): Cumplimiento e incumplimiento de las obligaciones, $3^{a}$ edición actualizada (Santiago, Editorial Jurídica de Chile).

JAFFEY, Peter (2013): "Restitutionary Remedies in the Contractual Context", en: The Modern Law Review (Vol. 76, № 3), pp. 429-463.

Llamas, Eugenio (1999): Cumplimiento por equivalente y resarcimiento del daño al acreedor (Madrid, Trivium).

LÓPEz DíAz, Patricia (2010): "La indemnización compensatoria por incumplimiento de los contratos bilaterales como remedio autónomo en el derecho civil chileno", en: Revista Chilena de Derecho Procesal (№15), pp. 65-113.

López Santa-María, Jorge (2010): Los contratos. Parte General, $5^{\text {a }}$ edición (Santiago, Legal Publishing).

Meza Barros, Ramón (2007): Manual de derecho civil. De las obligaciones (Santiago, Editorial Jurídica de Chile).

Palazón Garrido, María Luisa (2011): “El remedio resolutorio en la Propuesta de Modernización del Derecho de Obligaciones en España: Un estudio desde el derecho privado europeo", en: Jochen, Klaus (director), Derecho privado europeo y modernización del derecho contractual en España (Barcelona, Atelier), pp. 423-447. 
Peñailillo Arévalo, Daniel (2003): Obligaciones. Teoría General y Clasificaciones. La resolución por incumplimiento (Santiago, Editorial Jurídica de Chile).

Peñailillo Arévalo, Daniel (2011): Los bienes. La propiedad y otros derechos reales (Santiago, Editorial Jurídica de Chile).

Pinochet Olave, Ruperto y Concha Machuca, Ricardo (2015): "Las prestaciones mutuas en caso de nulidad de contrato: carácter indemnizatorio o restitutorio en el derecho civil chileno", en: Revista de Derecho Privado, Universidad del Externado ( $\left.N^{\circ} 28\right)$, pp. 29-152.

Pizarro Wilson, Carlos (2011): "Contra el efecto retroactivo de la resolución por incumplimiento contractual", en: Eliorraga, Fabián (director), Estudios de derecho civil VII. Jornadas nacionales de derecho civil Viña del Mar (Santiago, Thompson Reuters), pp. 449-460.

SmITs, Jan (2014): Contract Law: A Comparative Introduction (Cheltenham, Edward Elgar Publishing).

ThIBIERGUe, Catherine (2009): Nulidad, restituciones y responsabilidad, restitutions et résponsabilité (traducción Gustavo de Greiff, Bogotá, Universidad Externado Colombia).

VIRGO, Graham (2006): The Principles of the Law of Restitution (Oxford, OUP). ZimmermanN, Reinhard (1996): The Law of Obligations (Oxford, Clarendon Press).

ZimmermanN, Reinhard (2011): "The Unwinding of Failed Contracts in the Unidroit Principles 2010", en; Uniform Law Review (Vol. 16, № 3), pp. 563-587.

Zuloaga Ríos, Isabel. (2006): Teoría de la responsabilidad precontractual. Aplicaciones en la formación del consentimiento de los contratos (Santiago, LexisNexis).

\section{NORMAS CITADAS}

Código Civil chileno.

Código Civil alemán (BGB).

Código Civil francés (Code civil).

Código Civil italiano (Codice civile).

Convención de Viena sobre Compraventa Internacional de Mercaderías (CVCIM).

\section{JURISPRUDENCIA CITADA}

Feyerabend y otro con Bravo Vergara (2014). Corte Suprema, 20 de enero de 2014, rol 5818-13.

Moena con Quidel (2016). Corte Suprema, 2 de junio de 2016, rol 6528-2015. 
Continental Inmobiliaria y Servicios con Dattas Labadie Jean Pierre (2012). Corte Suprema, 30 de enero de 2012, rol 4198-2011.

Saleh con Álvarez (2011). Corte Suprema, 13 de junio de 2011, rol 1958-2010.

Díaz Zamora, Ma Teresa con Blanco Herrera, Ricardo (2009). Corte de Apelaciones de San Miguel, NNo identificador CL/JUR/2565/2009.

Cecinas La Preferida S.A. con Sociedad Comercial Salinak Limitada (2005). Corte Suprema, 27 de julio de 2005, rol 5320-2003.

Sumpter v Hedges [1898] 1 QB 673.

Bolton v Mahadeva [1972] 1 WLR 1009.

A-G v Blake, [2001] 1 AC 268.

Experience Hendrix LLC v PPX Enterprises Inc [2003] 1 All ER (Comm) 830. 
